\title{
Assessing the distribution, habitat, and population size of the threatened Dupont's lark Chersophilus duponti in Morocco: lessons for conservation
}

\author{
Jesús T. García, Francisco SuÁrez, Vicente Garza, Jorge H. Justribó

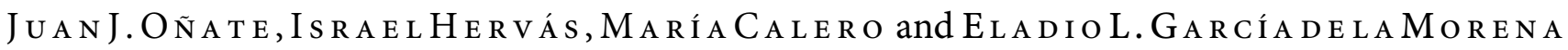

\begin{abstract}
Dupont's lark Chersophilus duponti was categorized globally as Near Threatened on the IUCN Red List in 2005 , largely because of reported declines in Spain and an estimated population of 2,000-3,000 breeding pairs in Morocco. However, the range and size of the species' North African populations were still unknown, despite being critical for assessment of the species' global conservation status. Here we report on the breeding distribution of Dupont's lark in Morocco, probably the largest population in its North African range, as well as on its preferred habitat, population density and size. Fieldwork and analysis of satellite images were combined to locate suitable habitat for the species, assess its presence (eliciting territorial calls by broadcasting the males' songs and calls), and estimate densities using $83 \mathrm{~km}$ of linear censuses. Total number of birds located was 461 (305 from song playback and 156 from transects) across an extent of occurrence of c. $11,000 \mathrm{~km}^{2}$, comprising $2,067 \mathrm{~km}^{2}$ of suitable habitat and an effective area of occupancy of $1,645 \mathrm{~km}^{2}$. Mean density was $0.60 \pm$ SD 0.52 birds per 10 ha and was highest in dense stands of Stipa tennacissima. Our estimate of Dupont's lark breeding population in Morocco is c. 15,400 singing males (lower and upper limits 11,220-20,167, respectively). Evidence of habitat loss and degradation was found in one of the main areas of the species' distribution in Morocco, although this does not seem to be a general pattern in the lark's Moroccan range. Further studies are required of the dynamics of suitable habitat for the species to prevent long-term consequences for the conservation of Dupont's lark and other bird species of the steppe.
\end{abstract}

Keywords Chersophilus duponti, distribution, Dupont's lark, Morocco, North Africa, steppe.

Jesús T. García* (Corresponding author), Francisco SuÁrez, Vicente Garza, Jorge H. Justribó, Juan J. Oñate, Israel Hervás, María Calero and Eladio L. García de la Morena Universidad Autónoma de Madrid, Department of Ecology, Darwin 10, E-28049 Madrid, Spain. E-mail jesus.ggonzalez@uclm.es

${ }^{*}$ Current address: Instituto de Investigación en Recursos Cinegéticos (IREC, CSIC, UCLM), Ronda de Toledo s/n E-13005 Ciudad Real, Spain.

Received 21 September 2006. Revision requested 3 November 2006. Accepted 19 December 2006.

\section{Introduction}

Most bird species inhabiting Mediterranean steppe1 like habitats are of conservation concern (BirdLife International, 2004). For most of these species population sizes and recent declines are well studied, and declines are known to be due to farming-related pressures and changes in land use (Knick \& Rotenberry, 1995; Le Cuziat et al., 2005). However, despite being of conservation concern in Europe, most of these species are categorized globally as Least Concern (IUCN, 2007), with important populations believed to be present in the steppe-like habitat of North Africa (Cramp, 1988). However, the precise ranges, population sizes and, most importantly, population trends of these North African bird populations are practically unknown. Given the accelerated pace of development in these countries (Green et al., 2002), it likely that these bird species are experiencing pressures similar to that which they experience in Europe. Knowledge of population trends of many of these steppe species in North Africa is thus required to establish their conservation status at the global scale.

Dupont's lark Chersophilus duponti is a typical example. The species is considered one of the least abundant passerine species in Europe (Garza et al., 2004). Its continental distribution is limited to the shrub steppes of the Mediterranean region of Spain, and its breeding population is 1,3001,900 territories (Garza et al., 2003, 2005; Tella et al., 2005). Dupont's lark is categorized as Endangered in Spain because of recent habitat loss driven by agricultural expansion, reforestation schemes and other land use changes (Garza et al., 2004).

Beyond Europe, the species' population size and distribution are poorly known, partly because of its secretive habits. It is considered to be sparsely distributed and uncommon in most areas of its relatively small and fragmented range, restricted in North Africa to the north of the Maghreb (Morocco, Algeria and Tunisia), Libya and Egypt (Cramp, 1988; De Juana \& Suárez, 2004). Within the African range, the nominal subspecies $C$. $d$. duponti is restricted to Morocco, northern Algeria and Tunisia, and is considered an evolutionary unit distinct from the European C. $d$. duponti (García et al., 2008), whereas the subspecies C. d. margaritae occurs throughout the rest of the African species' range. Detailed distribution, population size and trends in these countries are unknown. Only Blondel (1962) 
for Algeria and Suárez et al. (1986) for Morocco have reported on the species' abundance, all other available information being qualitative (see Thévenot et al., 2003 for Morocco; Isenmann \& Moali, 2000 for Algeria; Isenmann et al., 2005 for Tunisia). Despite the shortage of data, Dupont's lark was categorized globally as Near Threatened in 2005 (IUCN, 2007), reflecting the concern that its main North African populations may not have remained stable in recent decades (e.g. Isenmann et al., 2005 for Tunisia).

The purposes of this study were to (1) delimit the current distribution of Dupont's lark in Morocco, one of the largest breeding populations in its North African range (De Juana \& Suárez, 2004), (2) characterize its preferred habitat and estimate population density and size in Morocco, and (3) discuss the species' conservation status at the global level.

\section{Methods}

\section{Geographical range, habitat preferences and occurrence}

The whole distribution range of the species in Morocco (according to Thévenot et al., 2003) was searched (Fig. 1), totalling c. $90,000 \mathrm{~km}^{2}$ in eastern Morocco (from latitude $34^{\circ} 23^{\prime}$ to $32^{\circ} 11^{\prime} \mathrm{N}$ and from longitude $5^{\circ} \mathrm{O} 2^{\prime}$ to $1^{\circ} 50^{\prime} \mathrm{W}$ ) and the central Anti-Atlas $\left(31^{\circ} 24^{\prime}\right.$ to $30^{\circ} 22^{\prime} \mathrm{N}$ and $7^{\circ} 46^{\prime}$ to $\left.5^{\circ} 45^{\prime} \mathrm{W}\right)$, where there have been some recent records (Scheepen \& Meijer, 1996; Bergier, 2004). In eastern Morocco rangeland livestock is widespread along the flat high plateaux (rising to $>1,000 \mathrm{~m}$ ), sparsely covered by steppe vegetation dominated by halfa grass Stipa tennacissima. In this area (which includes Aïn-Benimathar, Rekkam and Midelt-Missour) the range extends west to the High Moulouya (with a similar landscape, although some crops are cultivated along the Moulouya River) and south to the Saharan Atlas (north of Jbel Maïz; Heim de Balsac, 1928). In the south-west of the species' range (the central AntiAtlas) steppe vegetation is dominant (mostly Artemisia spp. shrub), with interspersed crops in the valley bottoms (Thévenot et al., 2003). Climate is arid with an average rainfall of $210 \mathrm{~mm}$ per year, and is higher in the north $(300 \mathrm{~mm})$ and lower in the south $(120 \mathrm{~mm})$.

We visited all areas described as having suitable habitat for the species (Table 1) according to the described habitat preferences of the species in Morocco. We searched in dense halfa grass $(>15 \%$ cover $)$, sparse halfa grass $(<15 \%$ cover $)$,



FIG. 1 Distribution of Dupont's lark in Morocco, showing the four main areas in which the species occurs, and the villages and areas mentioned in the text (1, Midelt; 2, Merija; 3, Matarka; 4, Tendrara; 5, Aïn-Benimathar; 6, Boumalne Dadès; 7, Tiz-n-Taghatine). Polygons show the species' extent of occurrence in each region (see Methods), containing areas of occupancy (black areas) and areas of suitable habitat where the species was not recorded (grey areas). Small circles with arrows indicate the location of recent records (20032005) of the species during the breeding period (O. Fontaine \& A. Qninba, pers. comm.). Inset shows the location of the main map in Morocco. 
TABLE 1 Areas $\left(\mathrm{km}^{2}\right)$ of the five habitat types in which we found Dupont's lark in each of the four regions where the species is known or believed to occur, and overall (Fig. 1; see text for further details of habitat types and regions).

\begin{tabular}{|c|c|c|c|c|c|}
\hline Habitat type & $\begin{array}{l}\text { Aïn- } \\
\text { Benimathar }\end{array}$ & Rekkam & $\begin{array}{l}\text { Midelt- } \\
\text { Missour }\end{array}$ & $\begin{array}{l}\text { Anti- } \\
\text { Atlas }\end{array}$ & $\begin{array}{l}\text { Total } \\
\text { area }(\%)\end{array}$ \\
\hline $\begin{array}{l}\text { Dense halfa } \\
\text { grass }\end{array}$ & 161 & 511 & 877.5 & 0 & $1,549.5(75.0)$ \\
\hline Noaea shrub & 0 & 0 & 131.6 & 0 & $131.6(6.4)$ \\
\hline $\begin{array}{l}\text { Sparse halfa } \\
\text { grass }\end{array}$ & 27.3 & 0 & 87.9 & 0 & $115.2(5.6)$ \\
\hline $\begin{array}{l}\text { Hammada- } \\
\text { Stipa shrub }\end{array}$ & 0 & 0 & 8.2 & 0 & $8.2(0.4)$ \\
\hline $\begin{array}{l}\text { Artemisia } \\
\text { shrub }\end{array}$ & 0 & 0 & 0 & 262.6 & $262.6(12.7)$ \\
\hline Total & 188.3 & 511 & $1,105.2$ & 262.6 & $2,067.1(100.0)$ \\
\hline
\end{tabular}

and Artemisia spp. shrub on hard or pebbly soils, avoiding sand (Heim de Balsac \& Mayaud, 1962; Thévenot et al., 2003) but we also visited other vegetation types that offer the minimum vegetation cover and height needed by the species (according to available information for the Spanish population; Garza \& Suárez, 1990). Thus, we also searched in vegetation areas of Noaea mucronata (mixed sometimes with Anabasis articulata and Artrocnemum spp.), and species-mixed xerophytic vegetation of Hammada scoparia (sometimes with Lycium intrincatum and halfa grass), and including some areas with atypical vegetation such as Fredolia aretioides, or grassy-sandy areas. Only areas of flat or rolling terrain were searched because the species is absent from gradients steeper than $15 \%$, at least in Spain (Seoane et al., 2006).

We made six field visits between 2004 and 2006: December 2004 and December 2005 (10 and 15 days, respectively, by six people), March 2006 (12 days by six people), April 2005 (15 days by seven people), August 2005 (12 days by two people), and November 2005 (13 days by two people). In total the survey effort was 377 people days. Presence of the species was identified by visual or auditory detection of individuals, and eliciting territorial calls by broadcasting the males' territorial songs and calls (Garza et al., 2003). The latter took place anywhere in the surveyed patches, depending on accessibility and the feasibility of walking through the patches.

The alarm calls of Dupont's lark can be detected yearround (Laiolo et al., 2005), which enabled us to detect presence by playback trials at any time. The position of each detected bird (using a global positioning system, GPS, error $\pm 10 \mathrm{~m}$ ) and the habitat type (Table 1 ) in which it was found were recorded.

To estimate the extent of suitable habitat and the area in which the species is potentially distributed, we followed a three-stage method. Starting from the sites identified as containing the species, we used a GPS to geo-reference the boundaries of the habitat types present, up to a maximum distance of $5 \mathrm{~km}$. Boundaries were assessed by driving through, and/or scanning the area with binoculars and telescopes, when possible, from any available vantage points. The boundaries of these units were then confirmed and extended over nearby areas (to a maximum of $30 \mathrm{~km}$ ) by means of visual similarity analysis on satellite images (three Landsat ETM+ bands, GeoCoverTM, year 2000, pixel size $14.2 \times 14.2 \mathrm{~m}$ ). These homogeneous patches of habitat and their boundaries were rechecked and resampled in the following field visits, both to adjust geo-referencing of estimated boundaries and to check for the presence of the species. Survey coverage was thorough even for potentially less suitable habitat patches such as halfa grass with sparse cover, or species-mixed shrub vegetation.

\section{Extent of occurrence and area of occupancy}

All geo-referenced patches and bird locations were incorporated into the geographical information system Arcview v. 3.2 (ESRI, Redlands, USA). Following IUCN (2001) criteria, the extent of occurrence was measured as the area inside a minimum convex polygon (the smallest polygon in which no internal angle exceeds $180^{\circ}$ ) containing all the sites of recorded or inferred occurrence (i.e. all delimited patches with suitable habitat), and subtracting discontinuities of unsuitable habitat within the overall distribution of the species (IUCN, 2001). Area of occupancy was measured as the sum of the areas of delimited patches with suitable habitat within which the species was recorded.

\section{Population density and size}

The species' density was estimated by mapping all males during line transect censuses. Although other procedures could provide more fine results at the local scale (Garza et al., 2003) we used this method because of the constraints imposed by the large area surveyed and the time available. Because the extent of the different habitats was not homogeneous for a given region, the number of censuses in each habitat type was determined in relation to areal extent. Length of transects were 1,200-4,700 $\mathrm{m}$. Censuses were made only during the breeding season (field visits in March-April) and 30-60 minutes before sunrise, because Dupont's lark is most vocally active just before dawn (Aymí et al., 1994; De Juana \& Suárez, 2004) and most birds sing when flying (Cramp, 1988), which enabled us to discriminate between individuals and record their exact position. All individuals were geo-referenced by GPS to calculate their perpendicular distance to the transect line, and to avoid duplicated records. For analyses we only took into account individuals detected within $200 \mathrm{~m}$ either side of the transect line (see Garza et al., 2003, 2005, for a review of the problems associated with distance estimation for this species). We have assumed there are no differences in 
detectability between habitats because (1) we were unable to find evidence of different detectabilities in relation to habitat type in the literature, even on related species, (2) the habitat structure (vegetation cover and height) is similar in the habitats surveyed (J.T. García \& F. Suárez, unpubl. data) in these areas of Morocco, and (3) Dupont's lark's vocal activity during census time is maximal, and most singing birds were detected while flying.

Maximum, minimum and mean population sizes of Dupont's lark in each region were calculated as the product of the average density (and its 95\% upper and lower confidence limits) observed in each habitat and the area of each habitat type (Table 1). Calculations were made first for each studied area, and mean, minimum and maximum values for the total population of the species in Morocco were then calculated as the sum of estimated values for the regions surveyed.

\section{Results}

\section{Geographical range}

The total number of playback trials was 530, with a total trial time of 207 hours, and a total number of georeferenced Dupont's larks of 285. The distribution of trials among regions and habitat types is summarized in Table 2. The Moroccan distribution of Dupont's lark covers a wide geographical range (Fig. 1). In eastern Morocco we found the species in three regions: the high plateaux, from $30 \mathrm{~km}$ north to $45 \mathrm{~km}$ south of Ain-Benimathar (although breeding individuals were also detected west of Ain-Benimathar, near Merija); the Rekkam Plateau, north to Debdou and south to Matarka; the High Molouya, between Midelt and Missour south-east and Zeida and Enjil north-west. In the central Anti-Atlas region the species was present near
Tiz-n-Taghatine (15 Dupont's lark detected in 24 trials), but not in Boumalne Dadès $(n=23$ trials). Because we searched this latter region less intensively it is possible that some remnant populations may still occur there, principally close to Boumalne Dadès, where the species has been detected previously (Thévenot et al., 2003) and suitable habitat for the species exists. We did not detect the species either in the plains south of Tendrara $(n=92$ trials) or in the plain of Tafrata ( $n=10$ trials).

\section{Habitat}

The vegetation of sites in which we found Dupont's lark was typical of climax steppe vegetation in Morocco, generally dominated by relatively dense stands of halfa grass (Table 1). Qualitative differences in floristic composition and coverage were nevertheless found between regions (J.T. García \& F. Suárez, unpubl. data), with north-eastern sites dominated by dense halfa grass stands (especially in the Rekkam region), whereas non-degraded Artemisia shrub stands (with A. herba-alba and A. campestris) were scarce and almost exclusive to the Anti-Atlas. Dominant sparse halfa grass stands were found in the AïnBenimathar and Midelt-Missour regions, the latter presenting some Noaea mucronata shrub and mixed Hammada scoparia-Stipa tennacissima stands as well.

The area of suitable habitat for Dupont's lark in Morocco was estimated to be $2,067 \mathrm{~km}^{2}$ (Table 1 ). The main regions containing suitable habitat are Midelt-Missour $(53.5 \%)$ and Rekkam (24.7\%), and to a lesser extent the Anti-Atlas (12.7\%) and Aïn-Benimathar regions (9.1\%). Total extent of occurrence in Morocco was calculated to be $10,922.9 \mathrm{~km}^{2}$, comprising 37 patches of suitable habitat with an average and median surface of $66.05 \mathrm{~km}^{2}$ and $55.08 \mathrm{~km}^{2}$, respectively (Table 3 ).

TABLE 2 Number of playback trials and transect censuses, and Dupont's larks located, in each of the five habitat types in which we found the species in each of the four regions searched, and overall (Fig. 1; see text for further details).

\begin{tabular}{|c|c|c|c|c|c|c|c|c|c|c|}
\hline \multirow[b]{2}{*}{ Habitat type } & \multicolumn{2}{|c|}{ Aïn-Benimathar } & \multicolumn{2}{|l|}{$\underline{\text { Rekkam }}$} & \multicolumn{2}{|c|}{$\underline{\text { Midelt-Missour }}$} & \multicolumn{2}{|l|}{ Anti-Atlas } & \multicolumn{2}{|l|}{ Total (\%) } \\
\hline & No. & Birds & No. & Birds & No. & Birds & No. & Birds & No. & Birds \\
\hline \multicolumn{11}{|l|}{ Playback trials } \\
\hline Dense halfa grass & 143 & 112 & 114 & 34 & 130 & 87 & 0 & 0 & $387(73.0)$ & $233(81.7)$ \\
\hline Noaea shrub & 28 & 0 & 0 & 0 & 24 & 27 & 0 & 0 & $52(9.8)$ & $27(9.5)$ \\
\hline Sparse halfa grass & 9 & 0 & 0 & 0 & 18 & 8 & 0 & 0 & $27(5.1)$ & $8(2.8)$ \\
\hline Hammada-Stipa shrub & 0 & 0 & 0 & 0 & 10 & 2 & 0 & 0 & $10(1.9)$ & $2(0.7)$ \\
\hline Artemisia shrub & 7 & 0 & 0 & 0 & 0 & 0 & 47 & 15 & $54(10.2)$ & $15(5.3)$ \\
\hline Total (\%) & $187(35.3)$ & $112(39.3)$ & $114(21.5)$ & $34(11.9)$ & $182(34.3)$ & $124(43.5)$ & $47(8.8)$ & $15(5.3)$ & 530 & 285 \\
\hline \multicolumn{11}{|l|}{ Transect censuses } \\
\hline Dense halfa grass & 5 & 28 & 10 & 68 & 2 & 13 & 0 & 0 & $19(44.7)$ & $120(76.9)$ \\
\hline Noaea shrub & 3 & 0 & 0 & 0 & 2 & 9 & 0 & 0 & $5(13.2)$ & $9(5.8)$ \\
\hline Sparse halfa grass & 1 & 1 & 2 & 1 & 4 & 11 & 0 & 0 & $5(18.4)$ & $2(1.3)$ \\
\hline Hammada-Stipa shrub & 0 & 0 & 0 & 0 & 2 & 2 & 0 & 0 & $2(5.3)$ & $2(1.3)$ \\
\hline Artemisia shrub & 1 & 0 & 0 & 0 & 0 & 0 & 6 & 12 & $7(18.4)$ & $12(7.7)$ \\
\hline Total (\%) & $10(26.3)$ & $40(25.6)$ & $12(31.6)$ & $69(44.2)$ & $10(26.3)$ & $35(22.4)$ & $6(15.8)$ & $12(7.7)$ & 38 & 156 \\
\hline
\end{tabular}


TABLE 3 Descriptive parameters of the geographical range, and population estimate (in each of the five habitat types in which we found the species, and mean, maximum and minimum) of Dupont's lark in each the four regions in which the species was found (Fig. 1), and overall.

\begin{tabular}{|c|c|c|c|c|c|}
\hline Variable & $\begin{array}{l}\text { Aïn- } \\
\text { Benimathar }\end{array}$ & Rekkam & $\begin{array}{l}\text { Midelt- } \\
\text { Missour }\end{array}$ & $\begin{array}{l}\text { Anti- } \\
\text { Atlas }\end{array}$ & Total \\
\hline \multicolumn{6}{|l|}{ Geographical range } \\
\hline $\begin{array}{l}\text { Extent of } \\
\text { occurrence }\left(\mathrm{km}^{2}\right)\end{array}$ & $1,512.9$ & $2,850.3$ & $6,152.3$ & 407.4 & $10,922.9$ \\
\hline $\begin{array}{c}\text { No. of patches with } \\
\text { suitable habitat }\end{array}$ & 7 & 17 & 10 & 3 & 37 \\
\hline $\begin{array}{l}\text { No. of patches with } \\
\text { presence recorded }\end{array}$ & 4 & 7 & 8 & 1 & 20 \\
\hline $\begin{array}{l}\text { Area of occupancy } \\
\left(\mathrm{km}^{2}\right)\end{array}$ & 157.4 & 314.3 & $1,090.8$ & 83.0 & $1,645.4$ \\
\hline \multicolumn{6}{|l|}{ Population estimate } \\
\hline Dense halfa grass & 1,452 & 4,608 & 7,912 & 0 & 13,972 \\
\hline Noaea shrub & 0 & 0 & 63 & 0 & 63 \\
\hline Sparse halfa grass & 13 & 0 & 498 & 0 & 511 \\
\hline $\begin{array}{l}\text { Hammada-Stipa } \\
\text { shrub }\end{array}$ & 0 & 0 & 11 & 0 & 11 \\
\hline Artemisia shrub & 0 & 0 & 0 & 826 & 826 \\
\hline Mean & 1,465 & 4,608 & 8,484 & 826 & 15,383 \\
\hline Max. & 1,853 & 5,790 & 11,034 & 1,490 & 20,167 \\
\hline Min. & 1,079 & 3,426 & 6,553 & 162 & 11,220 \\
\hline
\end{tabular}

The presence of the species was confirmed in $54 \%$ of suitable habitat patches, covering at least $79.6 \%$ of the total area of suitable habitat estimated for the whole study area (Table 3). The size of patches differed significantly between occupied and unoccupied patches, being significantly higher in the former (mean $82.27 \pm \mathrm{SE} 18.37$ and $24.80 \pm \mathrm{SE}$ $7.83 \mathrm{~km}^{2}$, respectively: general linear model $F_{1,35}=7.33, \mathrm{P}=$ 0.010). Area of occupancy was calculated to be $1,645.4 \mathrm{~km}^{2}$ in 20 sub-areas with an average and median surface of $82.27 \mathrm{~km}^{2}$ and $63.44 \mathrm{~km}^{2}$, respectively (Table 3 ).

Dense stands of halfa grass appear to be the main habitat for the species in Morocco, containing 91\% of the total estimated population. Habitat dominated by Artemisia shrub (5.4\%) and sparse stands of halfa grass (3.3\%) were next in importance, and Noaea shrub (0.4\%) and mixed Hammada-Stipa shrub (0.1\%) appeared to be less important as habitat for the species.

\section{Population density}

After removing unclear records $(n=23)$, possible duplicate individuals $(\mathrm{n}=31)$, and birds detected at long distances $(\mathrm{n}=54)$, we had 156 geo-referenced individuals from transect censuses. A total of $82.7 \mathrm{~km}$ was censused, covering 3,308 ha (1,696 ha in 2005, and 1,312 ha in 2006). Density estimates (including six transects with no records of the species) ranged from 0.00 to 2.40 birds per 10 ha, averaging $0.60 \pm \mathrm{SD} 0.52$ birds per 10 ha. Dupont's lark density varied among habitat types (one way ANOVA $\left.F_{4,33}=6.08, \mathrm{P}<0.001\right)$, even when excluding censuses without positive responses $\left(F_{4,27}=2.90, \mathrm{P}=0.040\right)$, being highest in dense halfa grass (all censuses, $0.902 \pm$ SD 0.514 birds per $10 \mathrm{ha}$,$) and Noaea shrub habitat (0.567 \pm$ SD 0.267 birds per $10 \mathrm{ha}$ ), and lowest in sparse halfa grass (0.048 \pm 0.067 birds per 10 ha) and Hammada-Stipa shrub habitat $(0.137 \pm$ SD 0.087 males per 10 ha). Density in areas dominated by Artemisia shrub was intermediate $(0.315 \pm \mathrm{SD}$ 0.341 birds per 10 ha).

\section{Population size}

Our estimate of the total population size of Dupont's lark in Morocco is 15,400 males (Table 3). Highest estimated populations were in the regions of Midelt-Missour $(56.0 \%$ of the total population), and Rekkam (29.4\%), with AïnBenimathar region (9.3\%) and the Anti-Atlas (5.3\%) having smaller populations (Table 3).

\section{Discussion}

To our knowledge this is the first time that the population size of Dupont's lark has been estimated outside its European range (Thévenot et al., 2003). Our figure of 15,400 singing males in Morocco must, however, be considered as the minimum population, and interpreted with caution, because of two potential biases. Firstly, the extent of suitable habitat for the species is difficult to evaluate because of the detailed scale that is needed to reflect the relevant parameters appropriately, such as vegetation cover and composition, soil type and slope. Our method, based on successive approximations combining analysis of satellite images and intensive field work, appeared to be reliable, as confirmed by the discovery of individuals in apparently unusual habitats, such as mixed Hammada-Stipa shrub. Nevertheless, reported observations south of Matarka, in the furthest Rekkam region (O. Fontaine, pers. comm.; Fig. 1), in the north of Jbel Maïz (Heim de Balsac, 1928) and in the north of Jbel Grouz (A. Qninba, pers. comm.; Fig. 1), and near Boumalne Dadès, in the Anti-Atlas (Thévenot et al., 2003; Fig. 1), suggest that the species' distribution may extend beyond the areas we delimited in our study. However, densities will probably be low in these marginal sites because habitat (dominated by Lyceum intrincatum and Fredolia aretioides, or with sparse Artemisia spp.) searched there during our summer visit seemed poorly suited to the species. Hence, it is possible that the total Moroccan population could exceed our initial estimate by at most a few hundred males. Secondly, our estimate of density, which is lower than found in Spain (c. 0.7 birds per 10 ha in Morocco, and c. 1.o birds per 10 ha in Spain; Garza et al., 2005), has a higher variance because we censused over an area of occupancy of near 2,000 $\mathrm{km}^{2}$ of 
suitable but heterogeneous habitat. For example, the coefficient of variation of estimated densities in Spain is $19.9 \%$ (data from Tella et al., 2005) whereas it is $84.3 \%$ for Morocco. This is why there is a wide range $(11,220-20,167)$ in our estimate of the number of singing males in Morocco.

Our results also confirmed that halfa grass steppe is the main habitat for Dupont's lark in Morocco, supporting previous information on the species' habitat preferences (Thévenot et al., 2003). Differences in the size of occupied and unoccupied patches suggest that the species is sensitive to habitat fragmentation as we did not find it in smaller areas. The distribution of Dupont's lark is probably influenced by human activities. Overgrazing, land reclamation and burning are the main causes of the contraction and degradation of steppe habitat in Morocco (Benabid, 2000), affecting primarily dense halfa grass. Regression of these steppes has occurred since the beginning of the 2oth century in Morocco (and also in Algeria and Tunisia), with the area of steppe dominated by halfa grass undergoing a sharp decline (Quézel, 2000). All these factors increase habitat fragmentation but how they affected Dupont's lark in the past, and will do so in the future, is difficult to discern, especially given the shy and cryptic nature of the species.

In the mid 1980 s the species was continuously distributed throughout the plains of eastern Morocco bordering Algeria (Suárez et al., 1986), at which time these areas were characterized by a heterogeneous mosaic of dominant halfa grassland and Noaea shrub under low to medium livestock pressure, interspersed with extensive cereal plots. From our observations this landscape seems to have suffered three major changes, mainly because of human activities: (1) an expansion of intensively managed plantations of fodder shrubs (e.g. Atriplex spp.) to supply livestock, (2) a sharp decline in the total halfa grassland area, with many remaining stands severely affected by drought and by locust Schistocerca gregaria plagues in certain years (Ullman, 2006), and (3) an increase in the cover of sandy soils at the expense of hard and pebbly surfaces (in comparison to observations provided by Suarez et al., 1986). As a consequence, the area of habitat suitable for Dupont's lark in the high plateaux has diminished markedly in the last 2 decades. The area of halfa grass between Ain-Benimathar in the north and Tendrara in the south (a heterogeneous area c. $80 \times 30 \mathrm{~km}$ ) has almost disappeared since 1985 and remnants are severely degraded, with a high proportion of dead plants $(68.6 \pm 35.5 \%$ of halfa plants dead, $n=15$ sampled halfa grass patches). Decline of Dupont's lark populations in this area is therefore unsurprising. South to Tendrara, where the species had an abundance in 1985 similar to that in Aïn-Benimathar today (2.55 and 2.07 birds per 10 ha, respectively; Suárez et al., 1986) the species is virtually absent today. It is likely that other species linked to halfa grass, such as the scrub warbler
Scotocerca inquieta, which is almost non-existent today (J.T. García \& F. Suárez, unpubl. data) but was frequent in the 1980 os (Suárez et al., 1986), have also suffered consequent population declines in eastern Morocco during this period.

However, we have no evidence for similar large losses of habitat in the remaining distribution area of Dupont's lark in Morocco. Although no former records are available for comparative purposes from Midelt-Missour or Rekkam, we have not detected plantations of fodder crops or such high halfa grass mortality in these areas as in Tendrara (34.4 \pm SD $9.7 \%, n=41$, and $11.9 \pm$ SD $16.4 \%, n=21$, of plants dead from Midelt-Missour and Rekkam, respectively). However, in these areas we found a higher presence of complementary suboptimal habitats, such as Noaea and Hammada-Stipa shrubs, on which the species is able to persist, albeit at lower densities than in halfa grass. It is necessary, however, to develop effective management to prevent habitat degradation and population fragmentation that, in turn, may cause irreversible loss of habitat and significant long-term consequences for the conservation of Dupont's lark, as reported in other steppe-land bird species (Knick \& Rotenberry, 1995; Le Cuziat et al., 2005).

According to our conservative calculations, the Moroccan population is $>_{7}$ times larger than the European population, with c. 15,400 singing males in Morocco compared to 2,000 in Spain (Garza et al., 2003, 2005). The Moroccan and Spanish populations together probably amount to an important part of the global population of Dupont's lark, although the extent of the potential breeding range of the species in other North African countries could be even larger than in Morocco. Research is needed in Algeria, where the species' presence is probably related to halfa grass and Artemisia shrub coverage in the high plateaux and the north-western edge of the Sahara (Isenmann \& Moali, 2000), and in Tunisia where, in spite of a recently reported decline because of overgrazing and agricultural development (Isenmann et al., 2005), a significant area of the species' preferred habitats remains. Data are also needed for Libya and Egypt, where scattered and minor populations may remain (De Juana \& Suárez, 2004).

In summary, we found that Dupont's lark has a smaller population and a reduced breeding area in one region of its Moroccan range in comparison to quantitative records from 20 years ago, although this does not seem to be a general pattern in the lark's Moroccan range. More accurate information on the range and population size of the species elsewhere in North Africa is needed. Irrespective of the species' global conservation status, it is essential to study the medium and long-term dynamics of the species' habitat and the species' reproductive and population ecology across its North African range. We are now extending our field work to Tunisia, where preliminary data has shown that the population of Dupont's lark is low (Authors, unpubl. data), and we are planning future field work 
to assess the species in Algeria. The population of Dupont's lark in Morocco is still large but it may be only a matter of time before the species experiences critical declines similar to that of the European population. Finally, it is likely that this urgency is not exclusive to Dupont's lark and can be extended to other species of open Mediterranean habitats showing strong declines in Europe (e.g. the black-bellied and pin-tailed sandgrouses Pterocles orientalis and Pterocles alchata, Suárez et al., 1997) that have important, but as yet unquantified, North African populations (De Juana, 1997).

\section{Acknowledgements}

We would like to thank the Moroccan government for fieldwork permits, and M. Radi and M. Znari (Université Cadi Ayyad, Marrakech) for help with arrangements. E. Ramírez, R. del Pozo, A. Ramírez, J. Viñuela and the Colectivo Ornitológico Cigüeña Negra helped us during fieldwork. O. Fontaine and A. Qninba provided records of the south-eastern distribution of the species. J.L. Tella and an anonymous referee commented on and helped improve the manuscript. This study was funded by the Spanish Ministry of Environment (MMA) and the Spanish Agency for International Cooperation. Thanks are due to J.J. Areces and B. Heredia (MMA), who provided enthusiasm and institutional support.

\section{References}

Aymí, R., Elliot, A. \& Martínez, I. (1994) Els Ocells. In La Timoneda d'Alfés, pp. 32-35. Monografies de DEPANA, Lleida, Spain.

Benabid, A. (2000) Flore et écosystèmes du Maroc. Evaluation et preservation de la biodiversité. Ibis Press, Paris, France.

Bergier, P. (2004) Observations de Mai 2004 dans le sud marocain. Go-South Bulletin, 1, 18-22.

BirdLife International (2004) Birds in Europe: Population Estimation, Trends and Conservation Status. BirdLife International, Cambridge, UK.

Blondel, J. (1962) Donnés écologiques sur l'avifaune des Monts des Ksours (Sahara septentrional). Terre et Vie, 109, 209-251.

Cramp, S. (ed.) (1988) The Birds of the Western Palearctic, Vol. 5. Oxford University Press, Oxford, UK.

De Juan A, E. (1997) Family Peteroclidae (Sandgrouse). In Handbook of the Birds of the World, Vol. 4 (eds J. Del Hoyo, A. Elliott \& J. Sargatal), pp. 30-59. Lynx Edicions, Barcelona, Spain.

De Juana, E. \& SuÁrez, F. (2004) Dupont's lark Chersophilus duponti. In Handbook of the Birds of the World, Vol. 9 (eds J. Del Hoyo, A. Elliott \& D. Christie), pp. 568. Lynx Edicions, Barcelona, Spain.

García, J.T., Suárez, F., Garza, V., Calero-Riestra, M., Hernández, J. \& Pérez-Tris, J. (2008) Genetic and phenotypic variation among geographically isolated populations of the globally threatened Dupont's lark Chersophilus duponti. Molecular Phylogenetics and Evolution, 46, 237-251.

GARZA, V. \& SuÁREZ, F. (1990) Distribución, población y selección de hábitat de la Alondra de Dupont, Chersophilus duponti, en la Península Ibérica. Ardeola, 37, 3-12.
Garza, V., Traba, J. \& Suárez, F. (2003) Is the European population of Dupont's lark Chersophilus duponti adequately estimated? Bird Study, 50, 309-311.

Garza, V., Suárez, F. \& Tella, J.L. (2004) Alondra de Dupont, Chersophilus duponti. In Libro Rojo de las Aves de España (eds A. Madroño, C. González \& J.C. Atienza), pp. 309-312. Dirección General para la Biodiversidad-SEO/BirdLife International, Madrid, Spain.

Garza, V., Suárez, F., Herranz, J., Traba, J., García de la Morena, E.L., Morales, M.B. et al. (2005) Home range, territoriality and habitat selection of the endangered Dupont's lark (Chersophilus duponti): the breeding and postbreeding periods. Ardeola, 52, 133-146.

Green, A.J., El Hamzaoui, M., Aziz El Agbani, M. \& Franchimont, J. (2002) The conservation status of Moroccan wetlands with particular reference to waterbirds and to changes since 1978. Biological Conservation, 104, 71-82.

Heim de Balsac, H. (1928) Exploration ornithologique dans le sud Oranais et le Maroc oriental. Revue française d'ornithologie, 20, 174-188, 227-237, 279-286.

Heim de Balsac, H. \& Mayaud, N. (1962) Les Oiseaux du NordOuest de l'Afrique. Distribution géographique, écologie, migrations, reproduction. Encyclopédie Ornitologique X, Lechevalier, Paris, France.

Isenmann, P. \& Moali, A. (200o) The Birds of Algeria. SEOF, Paris, France.

Isenmann, P., Gaultier, R., El Hili, A., Azafzaf, H., Dlensi, H. \& Smart, M. (2005) Oiseaux de Tunisie. Société d'Études Ornithologiques de France, Paris, France.

IUCN (2001) 2001 Categories and Criteria (v. 3.1). IUCN, Gland, Switzerland [http://www.redlist.org/info/categories_ criteria2001.html, accessed 29 May 2006].

IUCN (2006) 2007 IUCN Red List of Threatened Species. IUCN, Gland, Switzerland. Http://www.iucnredlist.org [accessed 15 January 2007].

Laiolo, P., Vögeli, M., Serrano, D. \& Tella, J.L. (2005) Two new calls from the Dupont's lark Chersophilus duponti and imitations by other alaudids: ecological and monitoring implications. Ardeola, 52, 167-172.

Le Cuziat, J., Lacroix, F., Roche, P., Vidal, E., Médali, F., Orhant, N. \& Béranger, P.M. (2005) Landscape and human influences on the distribution of the endangered North African houbara bustard (Chlamydotis undulata undulata) in Eastern Morocco. Animal Conservation, 8, 143-152.

Knick, S.T. \& RotenberRy, J.T. (1995) Landscape characteristics of fragmented shrubsteppe habitats and breeding passerine birds. Conservation Biology, 9, 1059-1071.

Quézel, P. (2000) Réflexions sur l'évolution de la flore et de la vegetation au Maghreb méditerranéen. Ibis Press, Paris, France.

Scheepen, P. van \& Meijer, D. (1996) Dupont's lark outside known Moroccan breeding area. Dutch Birding, 18, 12-13.

Seoane, J., Justribó, J.H., García, F., Retamar, J., Rabadán, C. \& ATIENZA, J.C. (2006) Habitat-suitability modelling to assess the effects of land-use changes on Dupont's lark Chersophilus duponti: a case study in the Layna Important Bird Area. Biological Conservation, 128, 241-252.

Suárez, F., Fernández, A. \& De Lope, M.J. (1986) Effets de l'aridité sur la structure et la composition des communautes de Passeriformes des hauts-plateaux a alpha (Stipa tennacissima) au Maroc. Bulletin de l'Institut Scientifique Rabat, 10, 185-192.

Suárez, F., Martínez, C., Herranz, J. \& Yanes, M. (1997) Conservation status and farmland requirements of pin-tailed sandgrouse Pterocles alchata and black-bellied sandgrouse Pterocles orientalis in Spain. Biological Conservation, 82, 73-80. 
Tella, J.L., Vögeli, M., Serrano, D. \& Carrete, M. (2005) Status of the threatened Dupont's lark in Spain: overestimation, decline and extinction of local populations. Oryx, 39, 90-94.

Thévenot, M., Vernon, R. \& Bergier, P. (2003) The Birds of Morocco: An Annotated Checklist. British Ornithologists' Union, Tring, UK.

Ullman, M. (2006) African desert locusts in Morocco in November 2004. British Birds, 99, 489-491.

\section{Biographical sketches}

JESÚS T. GARCía researches the genetics, ecology and conservation of steppe birds, particularly intra- and interspecific competition, and also host-parasite interactions in arid environments. FRANCISCO SUÁREZ has carried out research on the relationships between agriculture, land-use changes and larks, and is coordinating a project on Dupont's lark in Spain. Vicente Garza works on the ecology and conservation of raptors and steppe birds and is also participating in the Dupont's lark project. Jorge H. Justribó works on ecology and conservation of steppe passerines and raptors and environmental impact assessment, and is also taking part in the Dupont's lark project. JUAN J. OÑATE works on the analysis of the design and impact of agricultural policies on biodiversity components, with a special focus on the EU's Common Agricultural Policy and pseudo-steppe birds. ISRAEL HERVÁS is currently participating in a research project on the ecology of steppe birds in Spain. María Calero works on the relationship between blood parasites and ecology of steppe birds. Eladio L. García de la Morena's work focuses on ecology and conservation of steppe birds and the environmental impact of human infrastructures. 